\title{
The story of Chinese characters $(0000-0010)$ when translated on Korean pronunciation
}

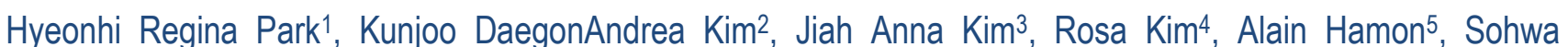
Therese Kim 6 , Sangdeog Augustin $\mathrm{Kim}^{7 *}$

1Department of Elderly care and welfare, Joongbu University, Kumsan, Republic of Korea ROK

2FarmHannong, LG Chemicals, Seoul, ROK

3Department d'Expertise economique, Universite de Paris-Est Creteil, Paris, France

${ }^{4}$ Specialite d'Economie politique, Ecole des Hautes Etudes en Sciences Sociales (EHESS), Paris, France

5L'Ecole Internationale Jean-Mermoz, Abidjan, Cote d'Ivoire

${ }^{6}$ Department of French language and literature, Seoul Women's University, Seoul, ROK

${ }^{7}$ Department of Companion animal and animal resources science, Joongbu University, Kumsan, ROK

*Corresponding Author

Sangdeog Augustin Kim

\section{Article History}

Received: 02.09 .2019

Accepted: 13.09 .2019

Published: 30.12 .2019

\begin{abstract}
We, the authors, tended to have interest on Chinese characters and their origin. It is considered that the people of Shang (or it was called as Eun) country, the second dynasty of old China has commenced the work of creation of Chinese characters. We tried to know the meaning of the randomly chosen 11 Chinese characters (0000-0010). At first, we analyzed the Chinese character into several parts, and then we pronounced those parts of a Chinese character on Korean pronunciation. We found next two things. At first Chinese characters are well understood if we translate the character on Korean pronunciation. And the second is that there are distinct differences between the original meaning and the present meaning; the original meaning is deeply stronger the presently used meaning. As a conclusion, it seems that the ancient Korean people have created the Chinese characters.
\end{abstract}

Keywords: 11 Chinese characters (0000-0010), Korean pronunciation, original meaning, present meaning, ancient Korean people.

\section{INTRODUCTION}

There are significant differences between China and Korea [1]. But those 144 letters of Tcheonzamun (Thousand character essay) were translated on Korean pronunciations by the present authors, and these poems were composed of 9 poems each 16 letters. We have got joy of studying "Tcheonzamun" [2-5], and we tended to have interest on Chinese characters and their origin [6]. It seems that the Chinese characters have been created more than 3000 years ago. And it is considered that the people of Shang (or it was called as Eun) country, the second dynasty of old China has commenced the work of letter creation [7]. How can we know their sense and their feeling of the ancient people? The possible route is the letters themselves. We can see through observing the Chinese characters the sense or the humor of the ancient people who created the Chinese characters.

\section{Materials ANd Methods}

We, the authors, do not know well if the old letters in Shang (or it was called as Eun) country are similar to the modern Chinese characters. We tried to know the meaning of the randomly chosen 11 Chinese characters $(0000-0010)$. At first, we analyzed the Chinese character into several parts, and then we pronounced those parts of one Chinese character on Korean pronunciation. This method is similar to the translation of Tcheonzamun (The thousand character essay) [2].

Copyright @ 2019: This is an open-access article distributed under the terms of the Creative Commons Attribution license which permits unrestricted use, distribution, and reproduction in any medium for non commercial use (NonCommercial, or CC-BY-NC) provided the original author and source are credited. 


\section{RESULT AND Discussion}

We tried to know the meaning of the randomly chosen 11 Chinese characters (0000-0010). At first, we analyzed the Chinese character into several parts, and then we pronounced those parts of a Chinese character on Korean pronunciation.

0000) Maeg (貃)

0000-1)

"Strike me! I can defeat you!" (the original meaning).

'Calm' (the present meaning).

0000-2)

'The Malgal people who live on the upper part of the district' (the original meaning).

'The Maeg people' (the present meaning).

0001) Heui( 希)

0001-1)

"I am truly looking for you, I miss you!" (the original meaning).

"I hope to see you again" (the present meaning).

0001-2)

"I hope that the man (the woman) will love me!" (the original meaning)

"I hope it" (the current meaning)

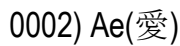

0002-1)

"I like you, but you do not like me!" (the original meaning).

"I like you!" (the present meaning).

0002-2)

"You don't like that I like you, do you?"

or

"Liking you makes you hate me, isn't it?" (The original meaning).

0002-3)

"Loving you makes me to come to you!" (the original meaning).

'Love' (the current meaning).

0002-4)

"Give her (him) the rice, and give again the rice to my loving woman(man)! I really wish to do this thing!" (The original meaning).

'The love' (The present meaning).

0003) Ko (古)

0003-1)

It is cold (the original meaning).

It is old (the present meaning).

0003-2)

"This language which we use now is the great language!" (the original meaning).

'It is old' (the current meaning).

0004) Zi(地)

0004-1)

'It is soil or earth' (the original meaning).

'It is soil or earth' (the present meaning).

0004-2)

'Somebody is disregarded by his (her) neighbors' (the original meaning).

'It is soil or earth' (the present meaning). 
0005) Hyeon (賢)

0005-1)

"The friend of the God!" We might say that he(she) becomes wise if the man(the woman) is on the side the Lord (the original meaning).

"She $(\mathrm{He})$ is wise or clever" (the present meaning).

0005-2)

"We get in high spirit!" (The original meaning).

"She(He) is wise or clever" (the present meaning).

0006) Kong(空)

0006-1)

"The heaven is really bright with red light from the Sun!" (The original meaning).

'The space is vacant and there is nothing' (The present meaning).

0007) Seo(西)

0007-1)

"There is no light, because the sun disappeared in the direction!" (The original meaning).

'It is west side' (The present meaning).

0007-2)

"Why do the people look at another people in the late afternoon? The reason is that the man (the woman) wants to be with other one on the time near to twilight, because he(she) feels solitary at the time of sunset" (The original meaning).

0007-3)

"Ah! Oh! It is the very place! (I want to come there!)" (the original meaning).

'It is the west' (the current meaning).

0008) Dong(東)

0008-1)

"I am able to start my work now! So I am happy!" (the original meaning).

'The side of east' (the present meaning).

0008-2)

"There are 8 vases while the flower is only one! (So I am going to gather more flowers)" (the original meaning).

'It is the east'(the current meaning).

0009) Kyeong(慶)

0009-1)

"It is truly bad, isn't it?" (the original meaning).

"It's a nice and good thing!" (the present meaning).

0009-2)

"It is a truly bad and disgusting thing, isn't it?" (the original meaning).

"It's a nice and good thing!" (the current meaning).

0009-3)

"If somebody is celebrated or in good condition, you are not happy and you will hate the man or the woman who is prosperous, aren't you?" (the original meaning).

'The celebrated thing' (The current meaning).

0010) Su(受)

0010-1)

"If you give me something!" (the original meaning).

"I receive it" (the present meaning).

0010-2)

"If you ask something with crying, you will receive it!" (the original meaning). 
'I receive it' (the present meaning).

0010-3)

"I receive the thing which you give me, because I like you!" (The original meaning)

'I receive it' (The current meaning)

We found next two things. At first Chinese characters are well understood if we translate the character on Korean pronunciation. And the second is that there are distinct differences between the original meaning and the present meaning; the original meaning is deeply stronger the presently used meaning. As a conclusion, it seems that the ancient Korean people have created the Chinese characters.

Conflict of Interests: The authors have not declared any conflict of interests.

\section{ACKNOWLEDGEMENTS}

We would like to thank Mr Ilsoo Joseph Kim and Mrs Bohwa Kim, Mr Yeonghag Park and Mrs Hilye Sarah Kim, to Ms Jieun Agatha Kim. We would like to thank Father Jean Blanc who came from France to Republic of Korea of Missions Etrangeres de Paris, who allowed us to read the book of "L'histoire de l'Eglise de Coree(History of Korean Catholic Church)". We would like to thank Father Hifumi Iwazaki who helped us when Augustin was a foreign student in Japan. We would like to thank Mrs Tamako Hayashi and Mr Yoshihiro Hayashi, Mrs Francine Tenaillon and Professor Nicolas Tenaillon for their supports during our stay in Japan and in France. We would like to thank the members of Cell praying group and Chorus members of Daejeon Nae-dong Catholic Church and the members of Daejeon Ludovicus of Ordo Francescan Secularis (OFS), the members of Yohan Moyim (in French 'le groupe de Jean Blanc').

\section{REFERENCES}

1. Dallet, C. H. (1874). Histoire de l'Eglise de Corée (History of Korean Catholic Church). Victor Palme. Paris. France, 11-99.

2. Kim, S. A., \& Park, H. R. (2016). Uri IISoo Josheph Abuzi Saenggag 18 (Uri Minzogeui Gussen lyagi-Tcheonzamun [Remember of my father Ilsoo Joseph 18 (Tcheonzamun is a story of our tolerant ancestors)].

3. Park, H. R., \& SA, K. (2016). Uriga Ilbon Yeohaengeul Danyeoon Nal Zeonyeog Rosaga Bonaezun Keul (" Zunim Tcheonzamun e Urinara lyagiga Nawayo!-Tcheonzamun Zeozaeui Aezeolhan Zeolgyuyo!")[An E-mail letter from Rosa on the night when we re turned from Japan journey (The sorrowful voices of Tcheonzamun's author in a Tcheonzamun poem and the petition of ancient Koreans to God)].

4. Park, H. R., Kim, J. A., Kim, K. D., Kim, J. A., Kim, S. T., Hamon, A., ... \& Kim, S. A. (2017). Lets make from now on the land of 0 ur mind broader! with a hidden meaning of We had better stop here completely!; from Translation of a Tcheonzamun (The Thous and Character Essay; written of 1000 letters in Chinese character) poem (657th-672nd letters). Journal of Languages and Cultur e, 8(2), 10-13.

5. Hyeonhi, R. P., Jieun, A. K., Kunjoo, D. A., Jiah, A. K., Sohwa, T. K., Kim, R., ... \& Sangdeog, A. K. (2017). Ancient Koreans peti tion to God in Tcheonzamun: The thousand character essay poem (641st to 656th letters). Journal of Languages and Culture, 8( 6), 79-84.

6. Park, H. R., \& Kim, S. A. (2012). Atchim Ilzigbuteo lleona Anzayaziyo (You must get up early in the morning). http://cafe.naver.c om/angolstar/1103.

7. Fairbank, J. K., \& Reischauer, E. O. (1978). China -Tradition and transformation. Houghton Mifflin Company. USA, 33-65. 